\title{
The Role of Finasteride in the Management of Androgenetic Alopecia in Male: A Narrative Review
}

\author{
Anil Tumkur*, Charmine Caryn Teo Cher Ern, Chang Ching Shuang, Amilia Chai Hui Yong, Chan Poh \\ Yee, Chai Tze Leen, Lee Kah Lock, Nermesh Singh
}

School of Pharmacy, International Medical University, Jalan Jalil Perkasa 19, Bukit Jalil, Kuala Lumpur, MALAYSIA.

\begin{abstract}
The purpose of this review was to evaluate the role of finasteride, a type-II 5 a-reductase inhibitor in the prevention and treatment of androgenetic alopecia (AGA) in males. Finasteride inhibits 5a-reductase and reduce the biosynthesis of dihydrotestosterone (DHT). This inhibition marks a decrease in concentration of DHT and provides a novel and selective approach to androgen deprivation. Clinical trials have proven the safety and efficacy of tablet finasteride $1 \mathrm{mg}$ for AGA. In this review, we discuss all aspects of finasteride, including dosing and indication, pharmacology, pharmacokinetics to its role in the treatment of AGA.
\end{abstract}

Key words: Androgenic alopecia, DHT, Finasteride, Norwood-Hamilton scale, Safety.

\section{INTRODUCTION}

Androgenetic Alopecia (AGA), also known as male pattern hair loss, is the most prevalent form of hair diminishment. Globally, it is estimated to affect half of men in their middle age (by the age of 50) and the prevalence increases with age. ${ }^{1-3}$ The occurrence varies by age and ethnicities, with White having higher prevalence compared to Asian and African-American ${ }^{2}$ It is exhibited by the developed loss of hair on the scalp in a characteristic distribution, with the front scalp, middle scalp, temporal scalp and vertex of scalp being the most common affected areas. $^{3-5}$

AGA is commonly classified by using the modified Norwood-Hamilton scale, which is a detailed classification system used worldwide. ${ }^{4}$ The severity is classified into Type I to VII, with increasing severity of hair thinning in the temples and vertex progressing to the entire top of scalp. ${ }^{4,6}$ There is a further variant from the normal classification termed Type A, which is majorly distinguished by receding hairline from the anterior border to the rear without leaving an island of hair in the mid-frontal region and the absence of a simultaneous development of bald spot on the vertex. ${ }^{4}$
The pathogenesis of AGA is shortening of a hair growing phase which dictates the hair length coined as anagen phase. ${ }^{5}$ This phase typically last 2 to 6 years with majority of the follicles in the normal scalp undergoing this phase. ${ }^{1}$ Shortened anagen phase causes follicular miniaturization in which the newly grown hair shaft is shorter and thinner. As more hair follicles undergo miniaturization, the coverage of hair around the scalp gradually diminishes. Eventually, the anagen phase becomes so short that hair produced by follicles fail to reach the skin surface. ${ }^{7}$

The main factor involved in the pathogenesis of AGA is elevated androgen levels. ${ }^{8}$ Men with AGA has higher cellular level of 5-alpha reductase, androgen receptors and also higher production rates of Dihydrotestosterone (DHT). ${ }^{3,9}$ The development of AGA may also be congenital, with genetic susceptible locus such as Androgen Receptor (AR)/ EDAR2 on the X chromosome being passed down from father to son. ${ }^{10}$

The current main treatment modality of AGA is pharmacological management. To date, only two drugs are approved by the Food and Drug Administration (FDA) for
DOI: 10.5530/ijopp.13.1.2

Address for correspondence: Dr. Anil Tumkur,

Senior Lecturer, School of Pharmacy, International Medical University, Jalan Jalil Perkasa 19, Bukit Jalil, Kuala Lumpur-57000, MALAYSIA.

Phone no: +60 122153997

Email Id: pharmacistanil@gmail. com

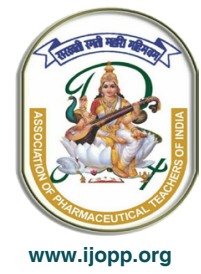


the treatment of $\mathrm{ADA}$, which are topical minoxidil and oral finasteride respectively., ${ }^{3,11,12}$ Other drugs such as dutasteride and spironolactone are potential treatments showing efficacy but yet to be approved for this indication. ${ }^{11,12}$ Non-medical treatment, such as low level laser treatment has recently gained favor as an over-thecounter treatment for hair regrowth, with a randomized control trial showing significant improvement in hair growth compared to placebo. ${ }^{13}$ In this review, we discuss in thorough the pharmacology, pharmacokinetics, safety and efficacy of oral finasteride $1 \mathrm{mg}$ daily in the management of AGA in males.

\section{Objective}

The objective of this review is to evaluate the efficacy and safety of finasteride on males with AGA through qualitative and quantitative analysis, including Global Photographic Assessment, Norwood-Hamilton scale, hair count, hair weight, serum Dihydrotestosterone (DHT), testosterone levels and adverse effects.

\section{Methodology}

We searched for articles in online databases which includes PubMed, ScienceDirect, SpringerLink, Scopus and Ovid. We included clinical trials testing the use of finasteride for the treatment of AGA in males. Selection of articles are based on several outcomes which are classified into qualitative outcomes, quantitative outcomes and adverse effects. The results of each of the outcomes are tabulated.

\section{Introduction}

Finasteride was initially developed by Merck as a drug to treat benign prostate hyperplasia in $1992 .{ }^{14}$ In a doubleblind study, we evaluated the effect of two doses of finasteride (1 $\mathrm{mg}$ and $5 \mathrm{mg}$ ) In December 1997, FDA approved finasteride to be used for the treatment of AGA in males at a dose of $1 \mathrm{mg}$ daily with the brand name Propecia. ${ }^{15-17}$ At that time, the only treatment for AGA was minoxidil, a topical solution. Propecia was the first orally administered drug proven to be effective for AGA treatment. ${ }^{16}$

Finasteride is a type-II $5 \alpha$-reductase inhibitor which has been shown to decrease levels of Dihydrotestosterone (DHT) in scalp and serum. It is administered orally with a dose of $1 \mathrm{mg}$ daily for the treatment of androgendependent hair disorders, including androgenetic alopecia. ${ }^{18}$

Finasteride is a synthetic 4-azosteroid which selectively and competitively inhibits $5 \alpha$-reductase enzyme.
$5 \alpha$-reductase is an important enzyme that is responsible for the conversion of testosterone to more potent Dihydrotestosterone (DHT) which is the preferred ligand for Androgen Receptor (AR) transactivation. ${ }^{19}$ In human body, $5 \alpha$-reductase appears in high concentrations especially in body areas such as the prostate gland, genital skin, frontal scalp and liver. Testosterone must be converted to DHT within the tissues in these body areas in order to initiate androgenic activity such as the growth of body hair. The conversion of testosterone to DHT is shown in Figure 1.

In the reduction of testosterone, Nicotinamide Adenine Dinucleotide Phosphate (NADPH) acts as a cofactor, which helps isoenzyme of $5 \alpha$-reductase to catalyze testosterone molecule resulting in an irreversible break of double bond between carbons 4 and 5 of testosterone molecule. In this case, Finasteride inhibits $5 \alpha$-reductase and reduce the biosynthesis of dihydrotestosterone. This inhibition marks a decrease in concentration of DHT and provides a novel and selective approach to androgen deprivation. ${ }^{20}$ Finasteride does not block the action of testosterone. In other words, the binding of testosterone or DHT to the androgen receptor is not affected. In addition, it does not possess androgenic or anti-androgenic properties as well as steroid hormonerelated properties. The finasteride concentration in plasma producing $50 \%$ of maximum intrinsic inhibition $\left(\mathrm{IC}_{50}\right)$ of the conversion of testosterone to DHT was stated to be $0.012 \mu \mathrm{g} / \mathrm{L} .{ }^{19}$

There are three types of $5 \alpha$-reductase isozymes, which are $5 \alpha$-reductase Type I, Type II and Type III (5 $\alpha$-R1-3). ${ }^{21}$ The type I $5 \alpha$-reductase isomer is expressed in sebaceous glands, sweat glands, dermal papillae cells and epidermal and follicular keratinocytes. Type II $5 \alpha$-reductase isomer is normally found in the outer root sheaths of hair follicles, the epididymis, vas deferens, seminal vesicles and prostate whereas Type III is normally found in peripheral tissues at higher level. ${ }^{22-25}$ Finasteride acts as a potent competitive inhibitor of Type II $5 \alpha$-reductase $\left[\mathrm{IC}_{50}=69 \mathrm{nM}\right]$. It also competitively inhibits Type III $5 \alpha$-reductase $\left[\mathrm{IC}_{50}\right.$ $=17.4 \mathrm{nM}$. However, it is a less potent competitive inhibitor of Type I $5 \alpha$-reductase $\left[\mathrm{IC}_{50}=360 \mathrm{nM}\right]$ as it has minimal selectivity for type I $5 \alpha$-reductase enzyme. ${ }^{26,27}$ Finasteride mainly acts as Type II $5 \alpha$-reductase, resulting in effective inhibition of the conversion of testosterone to Dihydrotestosterone (DHT) and reduce both scalp and serum DHT levels. ${ }^{28,29}$

\section{Pharmacokinetics}

Finasteride has an average measured oral bioavailability of $65 \%$ and its absorption is not affected by presence of 
food. ${ }^{17,30}$ Only $10 \%$ of circulating finasteride is freely or unbound to plasma proteins. The mean terminal half-life of finasteride is approximately $5-6 \mathrm{hr}$ in men between 18 60 years of age and $8 \mathrm{hr}$ in men older than 70 years of age. Following an oral dose of finasteride, approximately $40 \%$ of the dose was excreted in the urine as metabolites and approximately $57 \%$ in the faeces. ${ }^{30}$

Finasteride has the potential to cross the bloodbrain barrier, but it is undetectable in semen level. It is extensively metabolized in the liver, primarily via CYP3A4 to two major metabolites: monohydroxylation of the t-butyl side chain, which is further metabolized via an aldehyde intermediate to the second metabolite, a monocarboxylic acid. ${ }^{17,30}$ The metabolites are not active as they exhibit inhibitory activity of finasteride on 5-alpha reductase (Figure 2).

Finasteride has the potential to interact with some drugs that are also metabolised by hepatic enzymes, particularly CYP3A4 inhibitors. Clinically significant interactions may occur when finasteride is concomitantly used with erythromycin, carbamazepine, isoniazid and St. John's wort, hence close monitoring of hepatic or intestinal enzymes are required when these combinations are given together. ${ }^{31}$ On the other hand, results for interactions were insignificant justifying the unlikeliness of drug interaction with finasteride when antipyrine is consumed orally or as ear drops. ${ }^{19,32}$

No dosage adjustment is required in patients with renal impairment. ${ }^{17,33}$ In patients with chronic renal impairment, creatinine clearances ranging from 9.0 to 55 $\mathrm{mL} / \mathrm{min}$, majority of the concerned areas like - area under curve (AUC), maximum plasma concentration, halflife and protein binding are compared same as healthy volunteers. ${ }^{17}$ On the other hand, finasteride should be initiated cautiously in patients with hepatic function abnormalities since finasteride is mutually metabolised in liver. ${ }^{17,19}$ Also, patients with a large residual urinary volume or obstructive uropathy are not suitable candidates to be on finasteride therapy. ${ }^{33}$

\section{Efficacy}

\section{Qualitative outcomes}

Modified Norwood-Hamilton scale is often used as a standard to measure the severity of alopecia. ${ }^{34} \mathrm{~A}$ short 12 months study and a 10 years study were conducted with oral finasteride $1 \mathrm{mg}$ daily administration, with both studies concluded that improvements of one scale was presented in patients within a year time. Moreno-Arrones $\mathrm{OM}$ et al. ${ }^{35}$ Conducted a study in Spain among 10 femaleto-male transgender patients diagnosed with grade IV
AGA. All patients were administered with oral finasteride $1 \mathrm{mg}$ daily for at least 12 months. All the patients showed improvement of one scale for the Norwood-Hamilton scale within four to six months with no reported sexual or adverse effects. Concurrently, a 10 years follow-up study conducted by Rossi A et al. ${ }^{36}$ among 118 men at the range of 20 to 61 years old showed that $58.9 \%$ of patients at grade IV and V of AGA showed better improvements and $45.4 \%$ showed first improvement within a year time.

Global photographic assessment is a common and reliable tool used for the evaluation of any targeted area of the scalp to observe the changes in hair growth among patients. ${ }^{34,37,38}$ A standardized photographs were used to take photos of the patients' scalp condition with patient's head fixed in a stereotactic positioning device to ensure all photographs taken were at the same distance, same angle and same posture. ${ }^{34,37}$ Seven studies were conducted by using global photographic assessments as qualitative measures to evaluate the effectiveness of finasteride in the treatment of AGA among males. Both short-term and long-term studies were conducted ranging from 1-year trial to 5 years follow-up study.

Three studies were conducted for 1-year time among male patients with AGA above grade II to evaluate the efficacy of oral $1 \mathrm{mg}$ finasteride once daily. Kaufman KD et al. ${ }^{37}$ Conducted a study among 1553 men at the age of 18 to 41 years old who were diagnosed with grade II to $\mathrm{V}$ AGA was administered with oral finasteride $1 \mathrm{mg}$ or with placebo randomly. According to the global photographic assessment done every 6 months, the expert panels stated that $48 \%$ of Finasteride treated patients showed improvement at month 12 as compared to placebo (7\%). Besides, Olsen EA et al. ${ }^{38}$ also conducted a study 1553 male patients at the age of 18-60 years old with vertex hair loss and were administered with oral finasteride 1 $\mathrm{mg}$ or placebo. At 24 months, treatment with finasteride resulted in statistically significant $(P \leq 05)$ hair growth in all scalp regions as compared to those with placebo. $66 \%$ of younger men and $39 \%$ of older men treated with finasteride experience hair growth in the vertex area at month 24 . Woo YJ et al. ${ }^{39}$ also recruited 25 patients at the age of 18 to 40 years old and 15 patients of age above 41 years. The mean hair density after 1 year of treatment presented with improvement in both groups as compared to their baseline photographs. At the same time mean hair thickness among younger age group were slightly greater as compare to older age group however there were no significant difference between age groups. Hence, based on the two studies above, it could be concluded that finasteride $1 \mathrm{mg}$ daily administration is effective for younger men at 18 to 41 years as well as in men aged over 41 years. ${ }^{37,39}$ 
Another study conducted by $\mathrm{Hu} \mathrm{R}$ et al. ${ }^{34}$ to compare the efficacy of oral finasteride, topical minoxidil or the combination. 450 Chinese males at the age of 1850 years old diagnosed with grade II to VI AGA were recruited. The subjects were allocated into three different groups randomly, to be administered oral finasteride 1 $\mathrm{mg}$ daily, topical 5\% minoxidil twice daily and combined medication respectively. Rate of hair growth in finasteride and minoxidil group showed significant improvement at the third month $39.0 \%$ and $38.5 \%$ respectively; at the following 6, 9 and 12 months, patients consuming finasteride showed a more drastic improvement as compared to the minoxidil group $(p<0.01)$.

Besides, a 3.5 years study was conducted among 3177 Japanese men with AGA and was administered with oral finasteride $1 \mathrm{mg} .^{40}$ The efficacy of oral finasteride is ranging from $81.0 \%$ to $91.3 \%$ among grade II to V hair loss, with $91.3 \%$ patients at stage IV responded highest to the treatment. In addition, two 5 years follow-up studies were conducted among the Asian populations. Shin JW et al. ${ }^{23}$ stated that $44.4 \%$ of basic type AGA was presented with clinical improvement whereas $89.7 \%$ showed improvement in vertex type and $61.2 \%$ in frontal type. Both Shin JW et al. and Yoshitake et al. concluded that more than $85 \%$ of the patients was presented with observable improvement and almost $100 \%$ of them was present with no disease progression. ${ }^{23,41}$

In short, administration of oral finasteride $1 \mathrm{mg}$ once daily was associated with significant improvement in terms of quantitative outcomes among AGA males in any age groups. The first improvements in hair growth could be observed as soon as 3 months whereas in long term studies it could be observed that patients were presented with stable improvement and without further disease progression along the years (Table 1).

\section{Quantitative outcomes}

The evaluation of quantitative efficacy is based on hair count and hair weight. The subjects assessed are males with AGA with severity of at least grade II and above with respect to the modified Norwood-Hamilton classification. According to a study by Roberts JL et al. in $1999,{ }^{42}$ the optimal dose of finasteride for the treatment of AGA was determined to be $1 \mathrm{mg}$ daily, with superior improvements compared to 0.01 and $0.2 \mathrm{mg}$ daily and demonstrated similar improvements with $5 \mathrm{mg}$ daily based on the outcomes of patient and investigator assessment, clinical assessment and scalp hair count. Hence, the dose of $1 \mathrm{mg}$ daily is standardized to assess the significance in improvement of quantitative outcomes. A total of 9 studies were collected from year
1998-2009 to evaluate the effectiveness of finasteride in terms of quantitative measures. There are variations in the duration of study, ranging from 28 weeks to 5 years which measures the short-term and long-term therapeutic effects of finasteride.

There are 4 studies who showed the efficacy of finasteride in short-term ( $\leq 1$ year). For studies up to 6 months, Roberts JL et al. ${ }^{42}$ showed improvement in hair count by $75 \%$ while Hajheydari $\mathrm{Z}$ et al. ${ }^{43}$ obtained results of increased mean hair count from $137.89 \pm 35.33$ (baseline) to $153.56 \pm 36.28$. Van Neste $\mathrm{D}$ et al..$^{44}$ concluded that after 48 weeks of finasteride treatment, there is mean increase of 7.2 hairs in a $1 \mathrm{~cm}^{2}$ area compared to placebo (mean decrease of -10.1 hairs) and net improvement of total hair count of $17.3 \pm 2.5$ (mean $\pm \mathrm{SE}$ ). Two studies done by Leyden $\mathrm{J}$ et al. ${ }^{45}$ and Whiting DA et al. ${ }^{46}$ Showed that finasteride treatment resulted in increase in mean hair count of $9.6 \pm 1.5$ hairs (mean \pm SE) and significant increase of total terminal hairs compared to placebo.

Kaufman KD et al. ${ }^{37}$ in 1998 and has investigated the efficacy of finasteride for a duration of 2 years, displaying results of net improvement of 138 hairs compared with placebo. This study is continued up to 5 years, where results in 2002 showed that durable improvements in scalp hair growth are observed compared to placebo and slowed further progression of hair loss. ${ }^{47}$ Price VH et al. has also conducted two studies ${ }^{48,49}$ to investigate the short-term and long-term efficacy of finasteride after 96 weeks and 4 years treatment respectively in 2002 and 2006. The results from these two studies showed that after 96 weeks, the increase in mean hair count and hair weight are $15.4 \%$ and $35.8 \%$ respectively; while after 192 weeks, the increase is $21.6 \%$ and $20.3 \%$.

In summary, these 8 studies have proven that oral finasteride $1 \mathrm{mg}$ daily results in quantitatively significant improvements in males with AGA. Hair count and hair weight start to increase by 6 months of treatment and continue to provide clinical benefits up to at least 5 years (Table 2).

\section{Serum DHT and testosterone levels}

The serum levels of androgen Dihydrotestosterone (DHT) and testosterone in males with AGA are shown to be affected after treated with finasteride. They are found to have higher levels of DHT and increased expression of the androgen receptor (AR) gene. High level of androgen stimulates other sites of body hair growth while inhibits hair growth. ${ }^{50}$ The deposition of DHT at the androgen receptors present in the Pilosebaceous Unit (PSU), leads to shrinkage of the hair follicles 
Table 1: Summary of Articles Showing Qualitative Efficacy of Finasteride in Male AGA Patients.

\begin{tabular}{|c|c|c|c|c|c|c|}
\hline Author and Year & Title & $\begin{array}{c}\text { Sample } \\
\text { Size }\end{array}$ & Dose & $\begin{array}{l}\text { Study } \\
\text { Duration }\end{array}$ & Severity Grade & Qualitative Outcome \\
\hline $\begin{array}{c}\text { Moreno-Arrones } \\
\text { OM, Becerra A, } \\
\text { Vano-Galvan S. } \\
(2017)^{35}\end{array}$ & $\begin{array}{l}\text { Therapeutic experience } \\
\text { with oral finasteride for } \\
\text { androgenetic alopecia } \\
\text { in female-to-male } \\
\text { transgender patients. }\end{array}$ & 10 & $1 \mathrm{mg}$ & 1 year & $\begin{array}{l}\text { Norwood } \\
\text { Hamilton Grade } \\
\text { IV }\end{array}$ & $\begin{array}{l}\text { All the patients improved one } \\
\text { grade on the Norwood-Hamilton } \\
\text { scale after a mean of } 5.5 \text { months } \\
\text { (range } 4-6 \text { months) since the start } \\
\text { of finasteride treatment. }\end{array}$ \\
\hline $\begin{array}{c}\text { Rossi A, Cantisani } \\
\text { C, Scarnò M, } \\
\text { Trucchia A, } \\
\text { Fortuna MC, } \\
\text { Calvieri S. }(2011)^{36}\end{array}$ & $\begin{array}{c}\text { Finasteride, } 1 \text { mg daily } \\
\text { administration on male } \\
\text { androgenetic alopecia } \\
\text { in different age groups: } \\
\text { 10-year follow-up. }\end{array}$ & 118 & $1 \mathrm{mg}$ & 10 years & $\begin{array}{l}\text { Norwood } \\
\text { Hamilton Grade } \\
\text { IV - V }\end{array}$ & $\begin{array}{l}45.4 \% \text { showed first improvement } \\
\text { within a year time. }\end{array}$ \\
\hline $\begin{array}{l}\text { Kaufman KD et al. } \\
\qquad(1998)^{37}\end{array}$ & $\begin{array}{l}\text { Finasteride in the } \\
\text { treatment of men with } \\
\text { androgenetic alopecia. }\end{array}$ & 1553 & $1 \mathrm{mg}$ & 1 year & $\begin{array}{l}\text { Norwood } \\
\text { Hamilton Grade } \\
\text { II - V }\end{array}$ & $\begin{array}{l}\text { The expert panels stated that } 48 \% \\
\text { of Finasteride treated patients } \\
\text { showed improvement at month } 12 \\
\text { as compared to placebo }(7 \%)\end{array}$ \\
\hline $\begin{array}{l}\text { Olsen EA, Male } \\
\text { Pattern Hair Loss } \\
\text { Study Group } \\
(2012)^{38}\end{array}$ & $\begin{array}{l}\text { Global photographic } \\
\text { assessment of men } \\
\text { aged } 18 \text { to } 60 \text { years } \\
\text { with male pattern } \\
\text { hair loss receiving } \\
\text { finasteride } 1 \mathrm{mg} \text { or } \\
\text { placebo. }\end{array}$ & 1553 & $1 \mathrm{mg}$ & 1 year & - & $\begin{array}{l}\text { At } 24 \text { months, treatment with } \\
\text { finasteride resulted in statistically } \\
\text { significant }(P \leq 0.05) \text { hair growth } \\
\text { versus placebo in all scalp regions. }\end{array}$ \\
\hline $\begin{array}{l}\text { Woo YJ, Sohn KM, } \\
\text { Joo HJ, Kim JE, } \\
\text { Kang H. }(2017)^{39}\end{array}$ & $\begin{array}{l}\text { Comparative study } \\
\text { of the efficacy of } \\
\text { finasteride } 1 \mathrm{mg} / \mathrm{d} \text { on } \\
\text { different age groups } \\
\text { with androgenetic } \\
\text { alopecia. }\end{array}$ & 40 & $1 \mathrm{mg}$ & 1 year & - & $\begin{array}{l}\text { The mean hair density after } 1 \\
\text { year of treatment presented with } \\
\text { improvement in both groups } \\
\text { as compared to their baseline } \\
\text { photographs. But there were no } \\
\text { statistically significant differences } \\
\text { between two groups. }\end{array}$ \\
\hline $\begin{array}{l}\text { Hu R, Xu F, Sheng } \\
\text { Y, Qi S, Han Y, } \\
\text { Miao Y, Rui W, } \\
\text { Yang Q. (2015) }{ }^{34}\end{array}$ & $\begin{array}{l}\text { Combined treatment } \\
\text { with oral finasteride and } \\
\text { topical minoxidil in male } \\
\text { androgenetic alopecia: } \\
\text { a randomized and } \\
\text { comparative study in } \\
\text { Chinese patients. }\end{array}$ & 450 & $1 \mathrm{mg}$ & 1 year & $\begin{array}{l}\text { Norwood } \\
\text { Hamilton Grade } \\
\text { II - VI }\end{array}$ & $\begin{array}{l}\text { Rate of hair growth in finasteride } \\
\text { showed significant improvement } \\
\text { at the } 3^{\text {rd }} \text { month }(39.0 \%) ; \\
\text { At the following } 6,9 \text { and } 12 \\
\text { months, patients consuming } \\
\text { finasteride showed a more drastic } \\
\text { improvement as compared to the } \\
\text { minoxidil group }(p<0.01) \text {. }\end{array}$ \\
\hline $\begin{array}{l}\text { Sato A, Takedo A. } \\
\qquad(2012)^{40}\end{array}$ & $\begin{array}{c}\text { Evaluation of efficacy } \\
\text { and safety of finasteride } \\
1 \mathrm{mg} \text { in } 3177 \text { Japanese } \\
\text { men with androgenetic } \\
\text { alopecia. }\end{array}$ & 3177 & $1 \mathrm{mg}$ & 3.5 years & $\begin{array}{l}\text { Norwood } \\
\text { Hamilton Grade } \\
\text { II - V }\end{array}$ & $\begin{array}{c}\text { The efficacy of oral finasteride } \\
\text { is ranging from } 81.0 \% \text { to } 91.3 \% \\
\text { among stage II to stage } \mathrm{V} \text { hair } \\
\text { loss, with } 91.3 \% \text { patients at stage } \\
\text { IV responded highest to the } \\
\text { treatment. }\end{array}$ \\
\hline $\begin{array}{l}\text { Shin JW, Chung } \\
\text { EH, Kim MB, Kim } \\
\text { TO, Kim WI, Huh } \\
\text { CH. }(2018)^{23}\end{array}$ & $\begin{array}{l}\text { Evaluation of long-term } \\
\text { efficacy of finasteride } \\
\text { in Korean men with } \\
\text { androgenetic alopecia } \\
\text { using the basic and } \\
\text { specific classification } \\
\text { system. }\end{array}$ & 126 & $1 \mathrm{mg}$ & 5 years & $\begin{array}{l}\text { BASP } \\
\text { Classification B, } \\
\text { V, F. }\end{array}$ & $\begin{array}{c}44.4 \% \text { of basic type AGA } \\
\text { was presented with clinical } \\
\text { improvement whereas } 89.7 \% \\
\text { showed improvement in vertex } \\
\text { type and } 61.2 \% \text { in frontal type after } \\
5 \text { years of treatment. }\end{array}$ \\
\hline $\begin{array}{c}\text { Yoshitake T, } \\
\text { Takeda A, Ohki K, } \\
\text { Inoue Y, Sato A. } \\
(2015)^{41}\end{array}$ & $\begin{array}{l}\text { Five-year efficacy } \\
\text { of finasteride in } 801 \\
\text { Japanese men with } \\
\text { androgenetic alopecia. }\end{array}$ & 801 & $1 \mathrm{mg}$ & 5 years & $\begin{array}{l}\text { Norwood } \\
\text { Hamilton Grade } \\
\text { I - VII }\end{array}$ & $\begin{array}{l}99.4 \% \text { of the patients was } \\
\text { presented with observable } \\
\text { improvement and } 100 \% \text { was } \\
\text { presented with no disease } \\
\text { progression. }\end{array}$ \\
\hline
\end{tabular}

(miniaturization), produces shorter and thinner hair and results in hair loss. ${ }^{51,52} \mathrm{DHT}$ also has a higher affinity for androgen receptors than testosterone, competes with testosterone with the binding of androgen receptors and dissociates more quickly, leading to rapid turnover. ${ }^{52,53}$ The high amount of testosterone receptors in scalps is one of the features of AGA patient which is hereditary in nature. ${ }^{43}$ However, the severity of AGA is independent of the sexual hormone level but affected by factors like duration of alopecia or sensitivity of hair follicle cells to androgens. ${ }^{50}$ 
Table 2: Summary of Articles showing the Quantitative Efficacy of Finasteride in Male AGA Patients.

\begin{tabular}{|c|c|c|c|c|c|c|}
\hline Author and Year & Title & $\begin{array}{c}\text { Sample } \\
\text { Size }\end{array}$ & Dose & $\begin{array}{l}\text { Study } \\
\text { Duration }\end{array}$ & $\begin{array}{c}\text { Severity } \\
\text { Grade }\end{array}$ & Quantitative Outcome \\
\hline $\begin{array}{c}\text { Roberts JL, a } \\
\text { Vh'ginia Fiedler, b } \\
\text { Julianne Imperato- } \\
\text { McGinley et al. } \\
(1999)^{42}\end{array}$ & $\begin{array}{l}\text { Clinical dose ranging studies } \\
\text { with finasteride, a type } 2 \\
5 \alpha-\text {-reductase inhibitor, in men } \\
\text { with male pattern hair loss }\end{array}$ & 466 & $1 \mathrm{mg}$ & 6 months & $\begin{array}{l}\text { Norwood/ } \\
\text { Hamilton } \\
\text { grade IIIv and } \\
\text { IV }\end{array}$ & $\begin{array}{c}\text { At month } 6 \text {, finasteride } \\
\text { treatment increased hair count } \\
\text { by } 75 \% \text { and further improved } \\
\text { to } 91 \% \text { at month } 12 .\end{array}$ \\
\hline $\begin{array}{l}\text { K.D. Kaufman, E.A. } \\
\text { Olsen, D. Whiting } \\
\text { et al. }(1998)^{37}\end{array}$ & $\begin{array}{c}\text { Finasteride in the treatment } \\
\text { of men with androgenetic } \\
\text { alopecia }\end{array}$ & 1553 & $1 \mathrm{mg}$ & 2 years & $\begin{array}{l}\text { Norwood/ } \\
\text { Hamilton } \\
\text { classification } \\
\text { II vertex, III } \\
\text { vertex, IV or V }\end{array}$ & $\begin{array}{c}\text { Finasteride treatment } \\
\text { progressively increased } \\
\text { hair count over } 1 \text { year and } \\
\text { maintained throughout } 2^{\text {nd }} \text { year } \\
\text { (net improvement compared } \\
\text { with placebo are } 107 \text { hairs at } 1 \\
\text { year and } 138 \text { hairs at } 2 \text { years) }\end{array}$ \\
\hline $\begin{array}{c}\text { Finasteride Male } \\
\text { Pattern Hair Loss } \\
\text { Study Group } \\
(2002)^{47}\end{array}$ & $\begin{array}{l}\text { Long-term (5-year) } \\
\text { multinational experience } \\
\text { with finasteride } 1 \mathrm{mg} \text { in } \\
\text { the treatment of men with } \\
\text { androgenetic alopecia }\end{array}$ & 1553 & $1 \mathrm{mg}$ & 5 years & - & $\begin{array}{l}\text { Finasteride treatment for } \\
\text { long-term ( } 5 \text { years) lead to } \\
\text { durable improvements in } \\
\text { scalp hair growth compared } \\
\text { to placebo and slowed further } \\
\text { progression of hair loss. }\end{array}$ \\
\hline $\begin{array}{l}\text { Leyden J, Dunlap } \\
\text { F, Miller B, Winters } \\
\text { P et al. }(1999)^{45}\end{array}$ & $\begin{array}{c}\text { Finasteride in the treatment of } \\
\text { men with frontal male pattern } \\
\text { hair loss. }\end{array}$ & 326 & $1 \mathrm{mg}$ & 1 year & $\begin{array}{l}\text { Norwood/ } \\
\text { Hamilton } \\
\text { grade II, II } \\
\text { vertex, Ila, III, } \\
\text { or III vertex }\end{array}$ & $\begin{array}{c}\text { After } 1 \text { year, finasteride } \\
\text { treatment increased mean hair } \\
\text { count in a } 1 \mathrm{~cm}^{2} \text { area by } 9.6 \\
\pm 1.5 \text { hairs (mean } \pm \mathrm{SE} \text { ). This } \\
\text { improvement was maintained } \\
\text { throughout the } 2^{\text {nd }} \text { year. }\end{array}$ \\
\hline $\begin{array}{l}\text { D.A. Whiting, J. } \\
\text { Waldstreicher, M. } \\
\text { Sanchez, K.D. } \\
\text { Kaufman (1999) }\end{array}$ & $\begin{array}{l}\text { Measuring reversal of hair } \\
\text { miniaturization in androgenetic } \\
\text { alopecia by follicular counts } \\
\text { in horizontal sections of serial } \\
\text { scalp biopsies: Results of } \\
\text { finasteride } 1 \mathrm{mg} \text { treatment } \\
\text { of men and postmenopausal } \\
\text { women }\end{array}$ & 26 & $1 \mathrm{mg}$ & 1 year & - & $\begin{array}{c}\text { Finasteride treatment resulted } \\
\text { in significant mean increase in } \\
\text { the total terminal hairs after } 1 \\
\text { year compared to placebo that } \\
\text { has non-significant increase of } \\
1.0 \text { hairs. }\end{array}$ \\
\hline $\begin{array}{l}\text { Van Neste D, } \\
\text { Fuh V, Sanchez- } \\
\text { Pedreno P, Lopez- } \\
\text { Bran E et al. } \\
(2000)^{44}\end{array}$ & $\begin{array}{c}\text { Finasteride increases anagen } \\
\text { hair in men with androgenetic } \\
\text { alopecia. }\end{array}$ & 212 & $1 \mathrm{mg}$ & 48 weeks & $\begin{array}{l}\text { Norwood/ } \\
\text { Hamilton } \\
\text { grade IIv, IIIv, } \\
\text { IV and V }\end{array}$ & $\begin{array}{c}\text { At week } 48, \text { finasteride } \\
\text { treatment resulted in mean } \\
\text { increase of } 7.2 \text { hairs in a } 1 \\
\mathrm{~cm}^{2} \text { area compared to placebo } \\
\text { with mean decrease of }-10.1 \\
\text { hairs and net improvement of } \\
\text { total hair count of } 17.3 \pm 2.5 \\
\text { (mean } \pm \mathrm{SE} \text { ) }\end{array}$ \\
\hline $\begin{array}{l}\text { Price VH, Menefee } \\
\text { E, Sanchez M, } \\
\text { Ruane P, Kaufman } \\
\text { KD. }(2002)^{48}\end{array}$ & $\begin{array}{c}\text { Changes in hair weight } \\
\text { and hair count in men with } \\
\text { androgenetic alopecia after } \\
\text { treatment with finasteride, } 1 \\
\text { mg, daily }\end{array}$ & 66 & $1 \mathrm{mg}$ & 96 weeks & $\begin{array}{l}\text { Norwood/ } \\
\text { Hamilton } \\
\text { grade II, lia, } \\
\text { liv, III or IIIv }\end{array}$ & $\begin{array}{l}\text { At week } 96 \text {, the increase } \\
\text { in hair count (mean } \pm \text { SE) } \\
\text { of finasteride-treated group } \\
\text { compared to placebo is } \\
15.4 \pm 3.2 \% \text { and improvement } \\
\text { in hair weight is } 35.8-4.6 \% \text {. }\end{array}$ \\
\hline $\begin{array}{l}\text { Vera H.Price, } \\
\text { EmoryMenefee, } \\
\text { MatildeSanchez, } \\
\text { Keith D. Kaufman } \\
(2006)^{49}\end{array}$ & $\begin{array}{l}\text { Changes in hair weight in men } \\
\text { with androgenetic alopecia } \\
\text { after treatment with finasteride } \\
\text { (1 mg daily): three-and 4-year } \\
\text { results }\end{array}$ & 66 & $1 \mathrm{mg}$ & 4 year & $\begin{array}{l}\text { Norwood/ } \\
\text { Hamilton } \\
\text { grade II, lia, } \\
\text { liv, III or IIIv }\end{array}$ & $\begin{array}{c}\text { At week } 192, \text { the increase } \\
\text { in hair count of finasteride- } \\
\text { treated group compared } \\
\text { to placebo is } 21.6 \% \text { and } \\
\text { improvement in hair weight is } \\
20.3 \% \text {. }\end{array}$ \\
\hline $\begin{array}{l}\text { Hajheydari Z, } \\
\text { Akbari J, Saeedi } \\
\text { M, Shokoohi } \\
\text { L. }(2009)^{43}\end{array}$ & $\begin{array}{l}\text { Comparing the therapeutic } \\
\text { effects of finasteride gel and } \\
\text { tablet in treatment of the } \\
\text { androgenetic alopecia. }\end{array}$ & 45 & $1 \mathrm{mg}$ & 6 months & $\begin{array}{c}\text { Maximum } \\
\text { hair density } \\
20 \text { hairs } / \mathrm{cm}^{2} ; \\
\text { maximum } \\
\text { diameter of } \\
\text { the bald area } \\
<10 \mathrm{~cm}\end{array}$ & $\begin{array}{l}\text { After } 6 \text { months, finasteride } \\
\text { treatment increased the mean } \\
\text { hair count from } 137.89 \pm 35.33 \\
\text { (baseline) to } 153.56 \pm 36.28 \text {. } \\
\text { The mean number of terminal } \\
\text { hair at baseline is } 105.58 \pm \\
39.33 \text { and increased to } 118.61 \\
\pm 37.49 \text { after treatment. }\end{array}$ \\
\hline
\end{tabular}


Finasteride inhibits the conversion of free testosterone to DHT, significantly decreasing the levels of DHT with little changes in the testosterone level in the body. Studies have shown that taking finasteride decreases DHT level with a relatively stable testosterone level. ${ }^{28,50,52}$ Nonetheless some studies have shown that patients have slightly increase of testosterone level after treatment with finasteride without affecting its positive outcome..$^{50,54}$ Decreased amount of DHT increases the amount and percentage of anagen (growth phase) hair, hair count, hair weight and follicle length in the frontal scalp significantly. ${ }^{43,52} 98 \%$ of testosterone binds to sex hormone binding globulin (SHBG), does not transform to DHT so it is physiology inactive. . $^{5,53}$

Additionally, finasteride has high affinity to type II $5 \alpha$-reductase enzyme which predominantly present in the hair follicles. ${ }^{52}$ Even at a low dose (1 mg/day), the optimum effect on serum DHT and clinical result can be obtained..$^{50,54,55}$ Distribution of androgenic steroids can affect the pattern of hair growth. ${ }^{52}$ Frontal or vertex scalp contains a higher amount of DHT compared to the occipital scalp and finasteride curative effect can be only seen at vertex scalp hair. ${ }^{51-53} \mathrm{~A}$ significant decrease of DHT level is found to correlate with higher curative rate compared to those with unchanged serum levels of DHT but excessive decrease in androgen does not bring more benefits for the patient. ${ }^{50}$

On the other hand, the serum testosterone is regulated by hypothalamic anterior pituitary axis and the release of Luteinizing Hormone (LH) is under androgen feedback regulation. ${ }^{53}$ There is no significant difference for serum levels of LH between healthy controls and AGA patients, which suggests an impair in negative feedback mechanism involved in AGA patients. AGA patients with increased LH also shows lower curative rate. ${ }^{50}$ These results are tabulated in Table 3.

\section{Safety}

The most common adverse effects with finasteride use is impaired sexual function. According to a study by Irwig MS et al..$^{56}$ in 2011, among 71 subjects, the prevalence of new-onset sexual dysfunction was $94 \%$ for libido, $92 \%$ for erectile function, $92 \%$ for decreased arousal and $69 \%$ for orgasm problems. The sexual dysfunction persisted for 40 months from the discontinuation time of finasteride to the interview date. Following this study, Irwig $\mathrm{MS}^{57}$ conducted another study to show the persistent sexual side effect of finasteride ex-users which lasted for at least 3 months despite discontinuation of finasteride. Subjects from the previous study were re-assessed using Arizona Sexual Experience Scale (ASEX), 9-16 months after their initial interview. The ASEX consists of 5 questions that measure libido, arousal, erectile function, ability to reach orgasm and orgasm satisfaction. At reassessment persistent sexual side effects continued to be present in $96 \%$ of subjects and $89 \%$ of subjects continued to meet the definition of sexual dysfunction according to ASEX.

Patients reported changes are semen quality and volume, penis change or reduced sensation, decrease in spontaneous erections, testicular size or pain and in mental abilities $+/$ - depressive symptoms are $11 \%$, $19 \%, 9 \%, 15 \%$ and $17 \%$ respectively. The long-term neurological effects effects may be due to the reduced concentration of neuroactive steroids, affecting the plasticity of neuronal architecture in regions of brain which is responsible for sexual function.

Samplaski MK et al. ${ }^{54}$ studied the effects of finasteride on semen parameter. The average age of the 14 participants was 37 years. When on finasteride, 7 of them had severe oligospermia with an initial sperm concentration of $<5 \mathrm{M} / \mathrm{mL}$. These 7 men's increase in sperm count after discontinuation of finasteride was statistically significant (average 11.6-fold increase). No man had a decrease in sperm count after cessation of finasteride. This study concluded that finasteride reduced fertility and stopping the drug results in improved sperm parameter. On the other hand, study conducted by Overstreet JW et al. ${ }^{58}$ showed that $1 \mathrm{mg}$ finasteride has no significant effect on sperm concentration, total sperm ejaculate, sperm motility or morphology. The effect on prostate volume and Prostate-specific Antigen (PSA) were small and reversible on drug discontinuation. A randomised-control trial by D'Amico AV et al. ${ }^{59}$ in 2007 has found that all men treated with finasteride had decreased level of Prostatespecific Antigen (PSA) of 42\% at week 48 .

As a complement to human studies, animal studies were conducted to explain about finasteride-associated sexual side effects. A study by Romer B et al. ${ }^{60}$ has shown that reduction of $5 \alpha$-dihydrotestosterone and neuroactive steroids have a negative effect on sexual desire because of changes in brain plasticity and loss of neuroprotection. Finasteride was also found to reduce the number of proliferating, neural progenitor cells in the hippocampus region. According to a study by Zhang MG et al. ${ }^{61}$ in 2012, the tissue weights of the corpus cavernosum and prostate were reduced by $25.9 \%$ and $92.3 \%$ respectively in finasteride-treated rats. Histopathology revealed a significant atrophy of the prostate in finasteride-treated rats.

Besides sexual dysfunction, finasteride is also associated with depression side effect. A study was conducted by 
Table 3: Summary of Articles Showing the Effect of Finasteride on Serum DHT and Testosterone Levels in Male AGA Patients.

\begin{tabular}{|c|c|c|c|c|c|}
\hline $\begin{array}{c}\text { Author and } \\
\text { Year }\end{array}$ & Title & $\begin{array}{c}\text { Sample } \\
\text { size }\end{array}$ & Dose & $\begin{array}{c}\text { Study } \\
\text { duration }\end{array}$ & Quantitative outcome \\
\hline $\begin{array}{l}\text { Zhang Y, Xu J, } \\
\text { Jing J, Wu X, } \\
\text { Lv Z. }(2018)^{50}\end{array}$ & $\begin{array}{l}\text { Serum Levels of Androgen- } \\
\text { Associated Hormones Are } \\
\text { Correlated with Curative Effect } \\
\text { in Androgenic Alopecia in } \\
\text { Young Men. }\end{array}$ & 239 & $1 \mathrm{mg}$ & 2 weeks & $\begin{array}{l}\text { After treating with finasteride, the DHT } \\
\text { levels in patient decreased significantly } \\
(p<0.05) \text { and patient with decreased } \\
\text { level of DHT and free testosterone has } \\
\text { higher ratio of curative rate. }\end{array}$ \\
\hline $\begin{array}{l}\text { Ryu H.K., } \\
\text { Kim K.M., } \\
\text { Yoo E.A., Sim } \\
\text { W.Y., Chung } \\
\text { B.C. }(2005)^{52}\end{array}$ & $\begin{array}{l}\text { Evaluation of androgens in } \\
\text { the scalp hair and plasma of } \\
\text { patients with male-pattern } \\
\text { baldness before and after } \\
\text { finasteride administration. }\end{array}$ & 21 & $1 \mathrm{mg}$ & 5 months & $\begin{array}{l}\text { After treatment, the level of DHT and } \\
\mathrm{DHT} / \mathrm{T} \text { ratio were significantly lower } \\
\text { in vertex scalp and serum but not in } \\
\text { occipital scalp. }\end{array}$ \\
\hline $\begin{array}{l}\text { Hajheydari } \\
\text { Z, Akbari J, } \\
\text { Saeedi M, } \\
\text { Shokoohi L. } \\
(2009)^{43}\end{array}$ & $\begin{array}{l}\text { Comparing the therapeutic } \\
\text { effects of finasteride gel and } \\
\text { tablet in treatment of the } \\
\text { androgenetic alopecia. }\end{array}$ & 45 & $1 \mathrm{mg}$ & 6 months & $\begin{array}{l}\text { The terminal hair, size of bald area and } \\
\text { hair count between topical finasteride } \\
\text { (A) and oral finasteride (B) in each } \\
\text { month were not significantly different. } \\
\text { Both group shows increase in hair } \\
\text { count and terminal hair count. }\end{array}$ \\
\hline $\begin{array}{l}\text { Drake L, } \\
\text { Hordinsky } \\
\text { M, Fiedler V, } \\
\text { Swinehart J, } \\
\text { Unger WP, } \\
\text { Cotterill PC et } \\
\text { al. }(1999)^{28}\end{array}$ & $\begin{array}{l}\text { The effects of finasteride } \\
\text { on scalp skin and serum } \\
\text { androgen levels in men with } \\
\text { androgenetic alopecia. }\end{array}$ & 249 & $\begin{array}{c}0.01 \mathrm{mg} \\
0.05 \mathrm{mg} \\
0.2 \mathrm{mg}, 1 \\
\mathrm{mg}, \text { or } 5 \mathrm{mg}\end{array}$ & 42 days & $\begin{array}{l}\text { The DHT levels in scalp skin decreases } \\
\text { in all treatment group with higher doses } \\
\text { of finasteride gives greater reduction } \\
\text { than } 0.01 \mathrm{mg} \text { finasteride group (no } \\
\text { significant difference with placebo). }\end{array}$ \\
\hline $\begin{array}{l}\text { Samplaski M, } \\
\text { Lo K, Grober } \\
\text { E, Jarvi K. } \\
(2013)^{54}\end{array}$ & $\begin{array}{l}\text { Finasteride use in the male } \\
\text { infertility population: effects } \\
\text { on semen and hormone } \\
\text { parameters. }\end{array}$ & 24 & $\begin{array}{c}1.04 \mathrm{mg} \\
\text { (Average) }\end{array}$ & 57.4 months & $\begin{array}{l}\text { There is no change in the hormone } \\
\text { parameters of the patient on finasteride } \\
\text { after cessation. }\end{array}$ \\
\hline $\begin{array}{l}\text { Whiting D, } \\
\text { Olsen EA, } \\
\text { Savin R, } \\
\text { Halper L, } \\
\text { Rodgers A, } \\
\text { Wang L et al. } \\
(2003)^{55}\end{array}$ & $\begin{array}{l}\text { Efficacy and tolerability of } \\
\text { finasteride } 1 \mathrm{mg} \text { in men aged } \\
41 \text { to } 60 \text { years with male } \\
\text { pattern hair loss. }\end{array}$ & 424 & $1 \mathrm{mg}$ & 24 month & $\begin{array}{l}\text { In finasteride group, there is a } \\
\text { significant improvement in the men's } \\
\text { hair growth through the analysis of } \\
\text { global photographic assessment data. }\end{array}$ \\
\hline
\end{tabular}

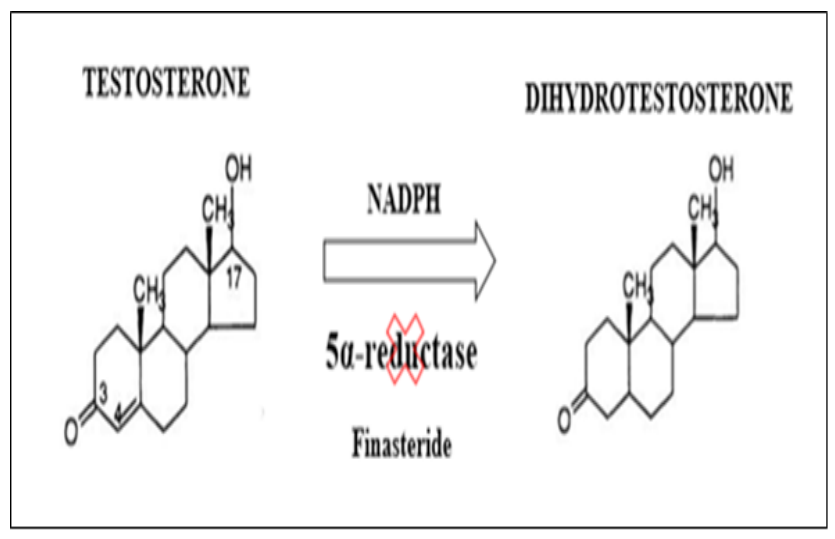

Figure 1: Conversion of testosterone to dihydrotestosterone (DHT). ${ }^{19}$

Irwig MS et al. ${ }^{62}$ on 61 finasteride ex-users with persistent sexual side effects and 29 men with MPHL who never use finasteride. The results showed that rates of depressive symptoms were significantly higher in finasteride former users. Depressive symptoms were found in $75 \%$ of the

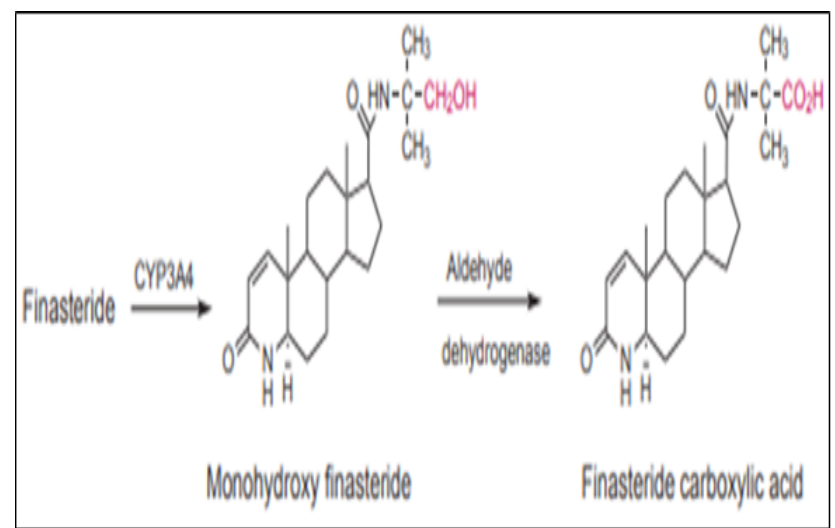

Figure 2: Formation of monohydroxy and carboxylic acid metabolites through CYP3A4 and aldehyde dehydrogenase as enzymes respectively. ${ }^{30}$

finasteride former users and $10 \%$ of the men in control group. Suicidal thoughts were present in $44 \%$ of the former finasteride users and in 3\% of the control group. The study concluded that finasteride reduces neuroactive steroids which may link to sexual dysfunction and 
Table 4: Summary of Articles on Finasteride-Associated Sexual Dysfunction.

\begin{tabular}{|c|c|c|c|c|c|}
\hline $\begin{array}{c}\text { Author and } \\
\text { year }\end{array}$ & Title & $\begin{array}{l}\text { Sample } \\
\text { size }\end{array}$ & Dose & Duration & Study outcome \\
\hline $\begin{array}{l}\text { Irwig MS, } \\
\text { Kolukula S. } \\
(2011)^{56}\end{array}$ & $\begin{array}{l}\text { Persistent sexual side } \\
\text { effects of finasteride for male } \\
\text { pattern hair loss. }\end{array}$ & 71 & - & - & $\begin{array}{l}\text { New-onset sexual dysfunction which persisted for } 40 \\
\text { months from the discontinuation time of finasteride to } \\
\text { the interview date. }\end{array}$ \\
\hline $\begin{array}{l}\text { Irwig MS } \\
(2012)^{57}\end{array}$ & $\begin{array}{l}\text { Persistent sexual side } \\
\text { effects of finasteride: could } \\
\text { they be permanent? }\end{array}$ & 54 & - & - & $\begin{array}{l}\text { At reassessment persistent sexual side effects } \\
\text { continued to be present in } 96 \% \text { of subjects and } 89 \% \\
\text { of subjects continued to meet the definition of sexual } \\
\text { dysfunction according to ASEX. }\end{array}$ \\
\hline $\begin{array}{l}\text { Samplaski } \\
\text { MK, Lo K, } \\
\text { Grober E, } \\
\text { Jarvi K. } \\
(2013)^{54}\end{array}$ & $\begin{array}{l}\text { Finasteride use in the male } \\
\text { infertility population: effects } \\
\text { on semen and hormone } \\
\text { parameters. }\end{array}$ & 14 & $\begin{array}{c}1.04 \mathrm{mg} \\
\text { (Average) }\end{array}$ & $\begin{array}{c}57.4 \\
\text { months }\end{array}$ & $\begin{array}{c}\text { There was statistically significant increase in sperm } \\
\text { count after the discontinuation of finasteride. No man } \\
\text { had a decrease in sperm count after cessation of } \\
\text { finasteride. }\end{array}$ \\
\hline $\begin{array}{l}\text { Overstreet } \\
\text { JW, Fuh VL, } \\
\text { Gould J, } \\
\text { Howards SS } \\
\text { et al. }(1999)^{58}\end{array}$ & $\begin{array}{l}\text { Chronic treatment with } \\
\text { finasteride daily does not } \\
\text { affect spermatogenesis or } \\
\text { semen production in young } \\
\text { men. }\end{array}$ & 181 & $1 \mathrm{mg}$ & 4 years & $\begin{array}{l}1 \mathrm{mg} \text { finasteride has no significant effect on sperm } \\
\text { concentration, total sperm ejaculate, sperm motility } \\
\text { or morphology. The effect on prostate volume and } \\
\text { prostate- specific antigen (PSA) were small and } \\
\text { reversible on drug discontinuation. }\end{array}$ \\
\hline $\begin{array}{l}\text { D'Amico AV, } \\
\text { Roehrborn } \\
\text { CG. }(2007)^{59}\end{array}$ & $\begin{array}{l}\text { Effect of } 1 \mathrm{mg} / \mathrm{day} \\
\text { finasteride on concentrations } \\
\text { of serum prostate-specific } \\
\text { antigen in men with } \\
\text { androgenic alopecia: a } \\
\text { randomised controlled trial. }\end{array}$ & 308 & $1 \mathrm{mg}$ & 4 years & $\begin{array}{l}\text { All men treated with finasteride had decreased level } \\
\text { of prostate-specific antigen (PSA) of } 42 \% \text { at week } \\
48 .\end{array}$ \\
\hline $\begin{array}{l}\text { Römer B, } \\
\text { Pfeiffer N, } \\
\text { Lewicka S et } \\
\text { al. }(2010)^{60}\end{array}$ & $\begin{array}{c}\text { Finasteride treatment } \\
\text { inhibits adult hippocampal } \\
\text { neurogenesis in male mice. }\end{array}$ & 63 & $100 \mathrm{mg} / \mathrm{kg}$ & 7 days & $\begin{array}{c}\text { Reduction of } 5 \text { a-dihydrotestosterone and } \\
\text { neuroactive steroids have a negative effect on sexual } \\
\text { desire because of changes in brain plasticity and loss } \\
\text { of neuroprotection. }\end{array}$ \\
\hline $\begin{array}{l}\text { Rahimi- } \\
\text { Ardabili B et } \\
\text { al. }(2006)^{63}\end{array}$ & $\begin{array}{l}\text { Finasteride induced } \\
\text { depression: a prospective } \\
\text { study. }\end{array}$ & 128 & $1 \mathrm{mg} /$ day & - & $\begin{array}{c}\text { Finasteride treatment increased both BDI and HADS } \\
\text { depression scores significantly. HADS anxiety } \\
\text { scores were increased, but the difference was not } \\
\text { significant. }\end{array}$ \\
\hline
\end{tabular}

depression. Another study was conducted by B RahimiArdiabili et al. ${ }^{63}$ on 128 finasteride users. Depression and anxiety were measured using Beck Depression Inventory (BDI) and Hospital Anxiety and Depression Scale (HADS). Finasteride treatment increased both BDI and HADS depression scores significantly. HADS anxiety scores were increased, but the difference was not significant (Table 4).

\section{CONCLUSION}

To summarise, finasteride showed significant improvement in the disease progression of AGA in males. The first improvements in quantitative and qualitative hair growth could be observed as soon as 3 months whereas in long term studies it could be observed that patients were presented with stable improvement and without further disease progression. On finasteride treatment, decreased level of DHT is closely related to the higher curative rate as significant positive outcomes are obtained especially at the vertex area. Slight increase or constant level of testosterone can be resulted from the treatment. Physicians should also discuss about the potential side effects of finasteride such as sexual dysfunction and depression to patients treated with finasteride for AGA.

\section{ACKNOWLEDGEMENT}

We are grateful to the school of Pharmacy, International Medical University, Kuala Lumpur for this Opportunity.

\section{CONFLICT OF INTEREST}

The authors declare that there are no conflicts of interest.

\section{ABBREVIATIONS}

AGA: Androgenetic alopecia; AR: Androgen receptor; DHT: Dihydrotestosterone.

\section{REFERENCES}

1. Price VH. Treatment of hair loss. N Engl J Med. 1999;341(13):964-73.

2. Kabir Y, Goh C. Androgenetic alopecia: Update on epidemiology, pathophysiology and treatment. J Egypt Women's Dermatol Soc. 2013;10(3):107-16.

3. Cranwell W, Sinclair R. Male Androgenetic Alopecia: Endotext. South Dartmouth (MA): MDText.com, Inc. 2000. [cited 2019 Mar 7]. Available from: http://www. ncbi.nlm.nih.gov/books/NBK278957/

4. Gupta M, Mysore V. Classifications of Patterned Hair Loss: A Review. J Cutan Aesthetic Surg. 2016;9(1):3-12.

5. Sinclair R, Torkamani N, Jones L. Androgenetic alopecia: New insights into the pathogenesis and mechanism of hair loss. F1000 Research. 2015;4(F1000 
Faculty Rev):585. [cited 2019 Mar 7] Available from: https://www.ncbi.nlm.nih. gov/pmc/articles/PMC4544386/

6. Habif T. Hair diseases. In: Clinical Dermatology, $5^{\text {th }}$ edition. Philadelphia: Elsevier. 2010.

7. Ellis JA, Sinclair R, Harrap SB. Androgenetic alopecia: Pathogenesis and potential for therapy. Expert Rev Mol Med. 2002;4(22):1-11.

8. $\mathrm{Ho} \mathrm{CH}$, Zito PM. Androgenetic Alopecia. In: Stat Pearls. Treasure Island (FL): Stat Pearls Publishing. 2018. Available from: http://www.ncbi.nlm.nih.gov/ books/NBK430924/

9. English RS. A hypothetical pathogenesis model for androgenic alopecia: Clarifying the dihydrotestosterone paradox and rate-limiting recovery factors. Med Hypotheses. 2018;111:73-81.

10. Vierhapper $H$, Nowotny $P$, Maier $H$, Waldhäusl W. Production rates of dihydrotestosterone in healthy men and women and in men with male pattern baldness: Determination by stable isotope/dilution and mass spectrometry. J Clin Endocrinol Metab. 2001;86(12):5762-4.

11. Varothai S, Bergfeld WF. Androgenetic alopecia: An evidence-based treatment update. Am J Clin Dermatol. 2014;15(3):217-30.

12. Kanti V, Messenger A, Dobos G, Reygagne P, Finner A, Blumeyer A, et al. Evidence-based (S3) guideline for the treatment of androgenetic alopecia in women and in men-short version. J Eur Acad Dermatol Venereol. 2018;32(1):1122.

13. Kim H, Choi JW, Kim JY, Shin JW, Lee SJ, Huh CH. Low-level light therapy for androgenetic alopecia: A 24-week, randomized, double-blind, sham devicecontrolled multicenter trial. Dermatol Surg Off Publ Am Soc Dermatol Surg Al. 2013;39(8):1177-83.

14. Gormley GJ, Stoner E, Bruskewitz RC, Imperato-McGinley J, Walsh PC, McConnell JD, et al. The effect of finasteride in men with benign prostatic hyperplasia. The Finasteride Study Group. N Engl J Med. 1992;327(17):118591.

15. Lanzafame RJ, Blanche RR, Bodian AB, Chiacchierini RP, Fernandez-Obregon A, Kazmirek ER. The growth of human scalp hair mediated by visible red light laser and LED sources in males. Lasers Surg Med. 2013;45(8):487-95.

16. Male Pattern Baldness Treatments. Medscape. 2010. [cited 2019 Mar 7]. Available from: https://www.webmd.com/skin-problems-and-treatments/hairloss/hair-loss-treatments-men\#1

17. Propecia (Finasteride). Available from: https://www.accessdata.fda.gov/ drugsatfda_docs/label/2011/0207880rig1s022lbl.pdf

18. Mysore V, Shashikumar BM. Guidelines on the use of finasteride in androgenetic alopecia. Indian J Dermatol Venereol Leprol. 2016;82(2):128-34.

19. Steiner JF. Clinical pharmacokinetics and pharmacodynamics of finasteride. Clin Pharmacokinet. 1996;30(1):16-27.

20. Stoner E. The clinical development of a 5 alpha-reductase inhibitor, finasteride. J Steroid Biochem Mol Biol. 1990;37(3):375-8.

21. Stiles AR, Russell DW. SRD5A3: A surprising role in glycosylation. Cell. 2010;142(2):196-8.

22. Zito PM, Syed K. Finasteride. In: Stat Pearls. Treasure Island (FL): Stat Pearls Publishing. 2018. [cited 2019 Mar 6]. Available from: http://www.ncbi.nlm.nih. gov/books/NBK513329/

23. Shin JW, Chung EH, Kim MB, Kim TO, Kim WI, Huh CH. Evaluation of long-term efficacy of finasteride in Korean men with androgenetic alopecia using the basic and specific classification system. J Dermatol. 2019;46(2):139-43.

24. Almohanna HM, Perper M, Tosti A. Safety concerns when using novel medications to treat alopecia. Expert Opin Drug Saf. 2018;17(11):1115-28.

25. Azarchi S, Bienenfeld A, Sicco KL, Marchbein S, Shapiro J, Nagler AR. Androgens in Women: Hormone modulating therapies for skin disease (Part II). J Am Acad Dermatol. 2019;80(6):1509-21.

26. Azzouni F, Godoy A, Li Y, Mohler J. The 5 Alpha-Reductase Isozyme Family: A Review of Basic Biology and Their Role in Human Diseases. Adv Urol. 2012;2012:1-18.

27. Tian G, Stuart JD, Moss ML, Domanico PL, Bramson HN, Patel IR, et al. 17 beta-(N-tert-butylcarbamoyl)-4-aza-5 alpha-androstan-1-en-3-one is an active site-directed slow time-dependent inhibitor of human steroid 5 alpha-reductase 1. Biochemistry. 1994;33(8):2291-6.

28. Drake L, Hordinsky M, Fiedler V, Swinehart J, Unger WP, Cotterill PC, et al. The effects of finasteride on scalp skin and serum androgen levels in men with androgenetic alopecia. J Am Acad Dermatol. 1999;41(4):550-4.

29. Olsen EA, Hordinsky M, Whiting D, Stough D, Hobbs S, Ellis ML, et al. The importance of dual 5alpha-reductase inhibition in the treatment of male pattern

hair loss: Results of a randomized placebo-controlled study of dutasteride versus finasteride. J Am Acad Dermatol. 2006;55(6):1014-23.

30. Wolff ME. Principles of Medicinal Chemistry, $4^{\text {th }}$ Edition Edited by William O. Foye, Thomas L. Lemke and David A. Williams. Williams and Wilkins, Philadelphia, PA. 1995. xii + 995 pp. $22 \times 28.5$ cm. ISBN 0-683-03323-9. \$70.00. J Med Chem. 1996;39(7):1567-8.

31. Finasteride (Rx). Medscape. [cited 2019 Feb 26]. Available from: https:// reference.medscape.com/drug/propecia-proscar-finasteride-342824\#0.

32. Antipyrine. Drug Bank. [cited 2019 Feb 25]. Available from: https://www. drugbank.ca/drugs/DB01435.

33. Finasteride: Drug Information. Lexicomp. 2013. [cited 2019 Mar 7]; Available from: https://www-uptodate-com.ezp2.imu.edu.my/contents/ finasteride-drug-information?search=finasteride\&source=panel_search result\&selectedTitle=1 52\&usage_type=panel\&kp_tab=drug_general\&display_ rank=1

34. Hu R, Xu F, Sheng Y, Qi S, Han Y, Miao Y, et al. Combined treatment with oral finasteride and topical minoxidil in male androgenetic alopecia: A randomized and comparative study in Chinese patients. Dermatol Ther. 2015;28(5):303-8.

35. Moreno-Arrones OM, Becerra A, Vano-Galvan S. Therapeutic experience with oral finasteride for androgenetic alopecia in female-to-male transgender patients. Clin Exp Dermatol. 2017;42(7):743-8.

36. Rossi A, Cantisani C, Scarnò M, Trucchia A, Fortuna MC, Calvieri S. Finasteride, $1 \mathrm{mg}$ daily administration on male androgenetic alopecia in different age groups: 10-year follow-up. Dermatol Ther. 2011;24(4):455-61.

37. Kaufman KD, Olsen EA, Whiting D, Savin R, DeVillez R, Bergfeld W, et al. Finasteride in the treatment of men with androgenetic alopecia. Finasteride Male Pattern Hair Loss Study Group. J Am Acad Dermatol. 1998;39(4 Pt 1):57889.

38. Olsen EA, Whiting DA, Savin R, Rodgers A, Johnson-Levonas AO, Round E, et al. Global photographic assessment of men aged 18 to 60 years with male pattern hair loss receiving finasteride $1 \mathrm{mg}$ or placebo. J Am Acad Dermatol. 2012;67(3):379-86.

39. Jun WY, Ki MS, Hong JJ. P144 Comparative study of the efficacy of finasteride 1 $\mathrm{mg} / \mathrm{d}$ on different age groups with androgenetic alopecia using phototrichogram analysis: A single-center retrospective analysis. JAAD. 2017;76(6 Supp1 1):AB78.

40. Sato A, Takeda A. Evaluation of efficacy and safety of finasteride $1 \mathrm{mg}$ in 3177 Japanese men with androgenetic alopecia. J Dermatol. 2012;39(1):27-32.

41. Yoshitake T, Takeda A, Ohki K, Inoue Y, Yamawaki T, Otsuka S, et al. Fiveyear efficacy of finasteride in 801 Japanese men with androgenetic alopecia. J Dermatol. 2015;42(7):735-8.

42. Roberts JL, Fiedler V, Imperato-McGinley J, Whiting D, Olsen E, Shupack $\mathrm{J}$, et al. Clinical dose ranging studies with finasteride, a type 2 5alphareductase inhibitor, in men with male pattern hair loss. J Am Acad Dermatol. 1999;41(4):555-63.

43. Hajheydari Z, Akbari J, Saeedi M, Shokoohi L. Comparing the therapeutic effects of finasteride gel and tablet in treatment of the androgenetic alopecia. Indian J Dermatol Venereol Leprol. 2009;75(1):47-51.

44. Neste DV, Fuh V, Sanchez-Pedreno P, Lopez-Bran E, Wolff H, Whiting D, et al. Finasteride increases anagen hair in men with androgenetic alopecia. $\mathrm{Br} \mathrm{J}$ Dermatol. 2000;143(4):804-10.

45. Leyden J, Dunlap F, Miller B, Winters P, Lebwohl M, Hecker D, et al. Finasteride in the treatment of men with frontal male pattern hair loss. J Am Acad Dermatol. 1999;40(6 Pt 1):930-7.

46. Whiting DA, Waldstreicher J, Sanchez M, Kaufman KD. Measuring reversal of hair miniaturization in androgenetic alopecia by follicular counts in horizontal sections of serial scalp biopsies: Results of finasteride $1 \mathrm{mg}$ treatment of men and postmenopausal women. J Investig Dermatol Symp Proc. 1999;4(3):282-4.

47. Finasteride Male Pattern Hair Loss Study Group. Long-term (5-year) multinational experience with finasteride $1 \mathrm{mg}$ in the treatment of men with androgenetic alopecia. Eur J Dermatol EJD. 2002;12(1):38-49.

48. Price VH, Menefee E, Sanchez M, Ruane P, Kaufman KD. Changes in hair weight and hair count in men with androgenetic alopecia after treatment with finasteride, $1 \mathrm{mg}$, daily. J Am Acad Dermatol. 2002;46(4):517-23.

49. Price VH, Menefee E, Sanchez M, Kaufman KD. Changes in hair weight in men with androgenetic alopecia after treatment with finasteride (1 mg daily): threeand 4-year results. J Am Acad Dermatol. 2006;55(1):71-4.

50. Zhang Y, Xu J, Jing J, Wu X, Lv Z. Serum Levels of Androgen-Associated Hormones are Correlated with Curative Effect in Androgenic Alopecia in Young Men. Med Sci Monit. 2018;24:7770-7. 
51. Wilson V, Siram K, Rajendran S, Sankar V. Development and evaluation of finasteride loaded ethosomes for targeting to the pilosebaceous unit. Artif Cells Nanomedicine Biotechnol. 2017;46(8):1-10.

52. Ryu HK, Kim KM, Yoo EA, Sim WY, Chung BC. Evaluation of androgens in the scalp hair and plasma of patients with male-pattern baldness before and after finasteride administration. Br J Dermatol. 2006;154(4):730-4.

53. Srivilai J, Minale G, Scholfield CN, Ingkaninan K. Discovery of Natural Steroid 5 Alpha-Reductase Inhibitors. ASSAY Drug Dev Technol. 2018;17(2):44-57. [cited 2019 Mar 7]. Available from: https://www.liebertpub.com/doi/10.1089/ adt.2018.870

54. Samplaski MK, Lo K, Grober E, Jarvi K. Finasteride use in the male infertility population: Effects on semen and hormone parameters. Fertil Steril. 2013;100(6):1542-6.

55. Whiting DA, Olsen EA, Savin R, Halper L, Rodgers A, Wang L, et al. Efficacy and tolerability of finasteride $1 \mathrm{mg}$ in men aged 41 to 60 years with male pattern hair loss. Eur J Dermatol. 2003;13(2):150-60.

56. Irwig MS, Kolukula S. Persistent Sexual Side Effects of Finasteride for Male Pattern Hair Loss. J Sex Med. 2011;8(6):1747-53.

57. Irwig MS. Persistent Sexual Side Effects of Finasteride: Could They Be Permanent?. J Sex Med. 2012;9(11):2927-32.
58. Overstreet JW, Fuh VL, Gould J, Howards SS, Lieber MM, Hellstrom W, et al. Chronic treatment with finasteride daily does not affect spermatogenesis or semen production in young men. J Urol. 1999;162(4):1295-300.

59. D'Amico AV, Roehrborn CG. Effect of $1 \mathrm{mg} /$ day finasteride on concentrations of serum prostate-specific antigen in men with androgenic alopecia: A randomised controlled trial. Lancet Oncol. 2007;8(1):21-5.

60. Römer B, Pfeiffer N, Lewicka S, Ben-Abdallah N, Vogt MA, Deuschle M, et al. Finasteride treatment inhibits adult hippocampal neurogenesis in male mice. Pharmacopsychiatry. 2010;43(5):174-8.

61. Zhang M, Wu W, Zhang C, Wang X, Gao P, Lu Y, et al. Effects of Oral Finasteride on Erectile Function in a Rat Model. J Sex Med. 2012;9(5):1328-36.

62. Irwig MS. Depressive Symptoms and Suicidal Thoughts among Former Users of Finasteride with Persistent Sexual Side Effects. J Clin Psychiatry. 2012;73(09):1220-3.

63. Rahimi-Ardabili B, Pourandarjani R, Habibollahi P, Mualeki A. Finasteride induced depression: A prospective study. BMC Clin Pharmacol. 2006;6(1):7. 